\title{
Side Activities of Non-Farmers in Rural Areas in the Netherlands
}

\author{
Marianna Markantoni and Dirk Strijker
}

\author{
Marianna Markantoni, Faculty of Spatial Sciences, Department of Cultural Geography, University of \\ Groningen, The Netherlands (M.Markantoni@rug.nl)
}

Dirk Strijker, Faculty of Spatial Sciences, Department of Cultural Geography, University of Groningen, The Netherlands (D.Strijker@rug.nl)

\begin{abstract}
In many rural areas, not only in The Netherlands but also elsewhere in Europe, has been observed a variety of employment opportunities for rural populations, following the decline in traditional agricultural employment. This contributes to the fact that the countryside is changing and rural areas can be viewed as new spaces of work. As a result, rural economy is no longer dominated by agricultural activities, but by activities such as small scale industrial production, service provision, landscape management, and residential use. To a certain extent these activities have the form of side-activities next to primary income sources. Most attention in both scientific literature and policies is focused on side-activities by farmers, such as agro-tourism and direct marketing. However, according to empirical data from The Netherlands, most side-activities are developed by non-farmers. In this paper the focus is on this last group. The amounts and types of non-farmers' and farmers side-activities will be deployed, together with their motives to start new entrepreneurship endeavors and the impact on the local community. It will be argued that this type of activities will stimulate rural economic development offering new job opportunities for income generation to the rural inhabitants and create new economic spaces in rural geographical contexts transforming the rural economy.
\end{abstract}

Keywords: entrepreneurship, rural areas, non-farmers, rural development, side-activities

\section{Introduction}

Rural areas are increasingly becoming spaces of consumption rather than only spaces of agricultural production (Ilbery 1998). Although agriculture is still often viewed as the mainstay of the rural economy, rural employment is no longer dominated only by agriculture. The decreasing number of farms has contributed to the replacement of agricultural activities by new economic activities (Gasson 1988; O'Connor et al. 2006; Van Depoele 2000; Van Huylenbroeck et al. 2004).

Diversity of economic activities has become a prominent theme in rural development in recent years. The countryside can offer new possibilities for new activities, such as camp sites, nature development and recreational sites in rural areas, and bed-and-breakfast or service firms in old farmhouses. This wide range of new emerging activities could not only offer the promise of ameliorating negative developments in rural areas (e.g. agricultural decline, rural depopulation and the onesided economic composition) but could also realign the economic base of rural areas with new societal demands, thereby strengthening it (Gurria 2007). The emergence of these new activities in rural areas take the form of both main and side activities. Main activities provide primary income (main occupation) while side activities have the potential to provide a secondary income for the rural household in addition to a separate main income source. 
With respect to rural diversification studies, the centre of attention has always been the farm household and the abilities of farmers to survive and to decrease their dependence on agricultural activities (Herslund 2007). Although many studies have been conducted on rural diversification based on new activities (main and side) initiated by farmers (Gasson 1988; Van der Ploeg 2003), little attention has so far been paid to the initiation of secondary activities in rural areas by non-farmers. Rural areas not only accommodate farmers but also other rural inhabitants, who can also can start secondary activities. Furthermore, as Oksa $(1991,9)$ concluded: 'most of the rural population in developed Western countries earns their livelihood from activities other than agriculture and forestry.... the future prospects of rural areas are more dependent on new activities in rural areas'. Our argument is that non-farmers can also contribute to rural development and stimulate new employment opportunities which are not connected to agriculture. However, side activities - especially when initiated by non-farmers - have been a sorely neglected aspect of rural development. A comparison between farmers and non-farmers with side activities should reveal the potential role of the latter group on rural area development, hence the present focus on the side activities of non-farmers.

\section{Defining side activities}

Different terms and definitions have been used in the literature to describe side activities mainly in the context of those conducted by farmers and farmers' wives. Terms such as non-farm activities, diversified activities, other gainful activities and para-agricultural farm enterprises have been broadly used to describe secondary activities (e.g. Carter 2001; Gasson 1988).

Side activities as we define them are a type of small home-based activity found in rural areas. Economically, they have the potential to provide a secondary but not a main source of income for a household. Owners are often sole traders, employing few or no people and the majority of them have a job elsewhere, while simultaneously conducting a side activity. They are categorized into service and facilities provision, tourism/recreation, arts and crafts, and producing and selling products.

There are a number of reasons why we are focusing on side activities. First, little is known about them, partly because many are not officially registered and because no data from other sources are available. Secondly, as side activities are economic activities, this may have economic effects for rural areas which may be of relevance to future rural policies. Additionally, because side activities are considered to be smallscale activities and involve a variety of activities ranging from tourism, services, arts and home-made products, they may hold the promise of improving the character and the attractiveness of the countryside for residents and visitors. Furthermore, side activities are easier to initiate than main activities as they do not require a large amount of resources to start up (land/space, credit, employees) and involve less risk, there is barely a threshold to entry.

\section{An explorative study}

In this paper we compare two groups of people with side activities - farmers and non-farmers. Because we do not know much about side activities, this study is explorative in nature. We base the comparison on the initiators' profiles and their motivations for starting a side activity. Examining their motivations should reveal what types of activities there are. For example, are side activities' owners interested in earning extra income to support a lifestyle, or just socializing? Motivations may also be a key factor in revealing the future potential of these activities. Finally, there is an underlying policy question. So far, mainstream rural policies do not take the side 
activities owned by non-farmers into account. Accordingly, understanding the rationale behind them could be a key factor in recognizing the specific goals and needs of this group.

We begin this paper with a description of methodology. We then describe the types of side activities, the profile of their practitioners, and theoretical and empirical considerations of educational levels and gender differences. We consistently compare start-up motivations and, in the final section, we propose future research opportunities.

\section{Methodology and data collection}

We performed systematic research in the rural areas of five Dutch municipalities in order to find side activities (Map 1). Rural areas in this study are geographically defined as areas outside built-up areas, outside village borders, thus in the countryside. The main difficulty of this research was to actually find the activities. Because many are not registered at the local Chamber of Commerce or in the records of professional associations, we had to locate them by travelling through the rural areas in the selected municipalities and spotting them by their roadside signs. A bias of this study is that only activities that were visible from the road were confirmed and that means that we may have missed cases. However, simply finding a roadside sign was not enough to know if the activity was a side activity. Therefore, in every case the owners were asked to identify whether the activity was providing an extra source of income in addition to their main occupation.

This scoping study was performed by means of a survey in order to gain a preliminary understanding of these types of activities, since no data from other sources were initially available. This method proved to be efficient for this study, given that the data were collected over a short period. We surveyed all the owners of the ninety-three side activities we spotted but we will present on eighty-four of the ninety-three cases in this paper, as not all data were available in every case. The results of this study are indicative, showing the difference between the two groups, farmers and non-farmers.

\section{Location selection}

As side activities are found in rural areas, a variety of different types of municipalities were chosen to cover a variety of different types of rural areas, from the most to the least remote and populated. Firstly, the municipality of Reiderland was chosen because it is considered one of the most remote areas in the Netherlands, situated as it is in the north-east and near the German border. Haarlemmermeer on the other hand was chosen for its highly populated rural area near the urban centre of Amsterdam. The municipality of Midden-Drenthe was selected as a popular tourist destination in the Netherlands, possibly implying that more side activities would be found there. Finally, the municipalities Noordenveld and Ooststellingwerf were chosen because they are considered to be rural municipalities and for the practical reason that they were near to our research institute. 


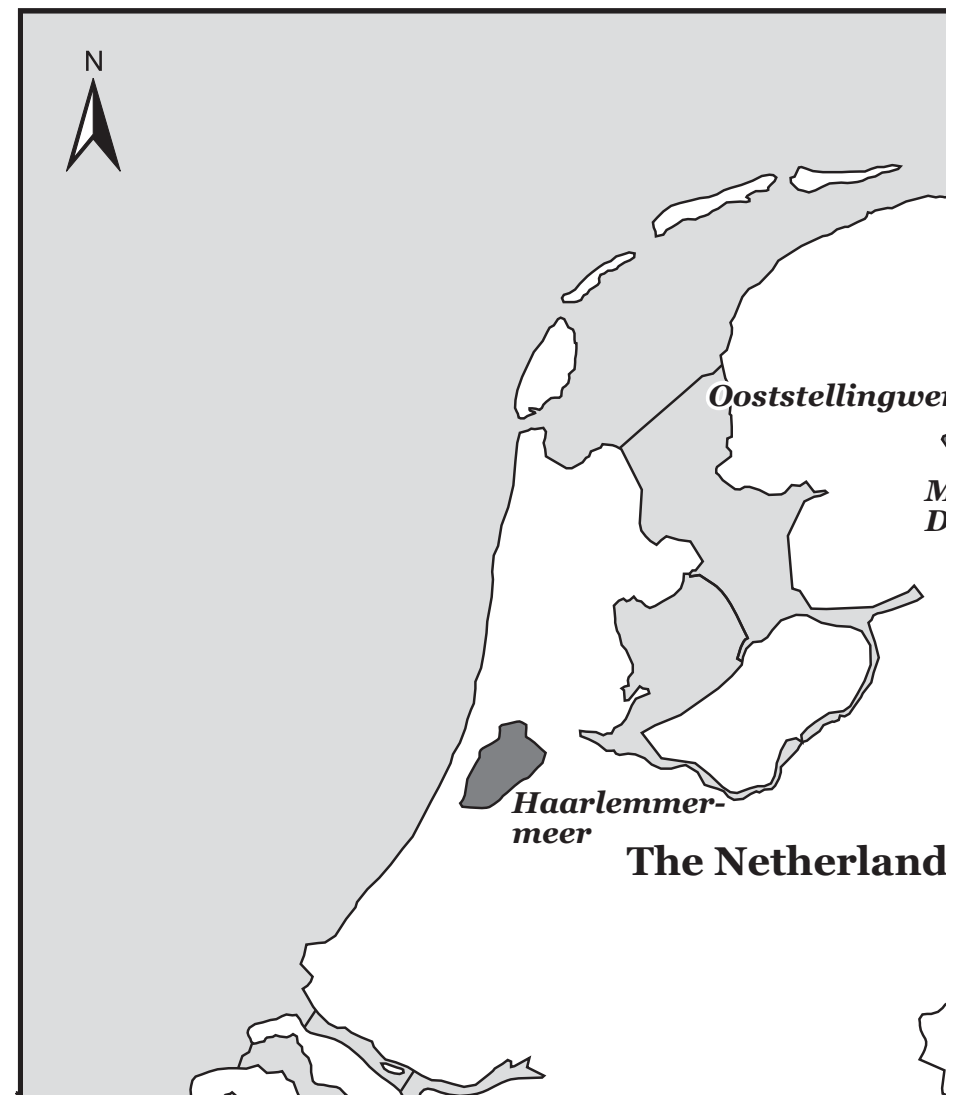

Map 1: The municipalities studied

\section{The profile of the side activities and their initiators}

Most of the literature on secondary activities or multifunctional activities in rural areas is about farmers (Van Huylenbroeck et al. 2004). Farmers have the resources available to start a secondary activity for a number of reasons. Firstly, they probably have the necessary land required. Secondly, as a result of the mechanization and automation of agriculture they often have spare time to start an additional economic activity on their farm. Another point is that farmers have already created networks and contacts with customers and professional associations, which facilitates the establishment of new activities. Fourthly, farmers are under pressure due to agricultural decline and are possibly looking for alternatives to increase their income.

The non-farmer entrepreneur group has not been paid much attention in literature. It is likely that non-farmers do not have as many resources or networks as farmers. However, they may have resources available in terms of money and space and they may also have knowledge of the product or the market. Alternatively, such entrepreneurs could be starting side activities for other reasons, such as to support a rural lifestyle. In this scoping study, we found that there are more non-farmer owners with side activities in the countryside than farmers. Side activities were initiated by nonfarmers in $71 \%$ of cases, with farmers accounting for the rest (Table 2). This underlines the importance of this group. Broekhuizen et al. (1997) in 'Renewing the Countryside', draw on examples of main and side activities in the Netherlands which show that rural inhabitants can extend their activities beyond pure agriculture. They concluded that all these activities are capable of having a positive impact on the development of the countryside. After emphasizing the distinction between farmers and non-farmers, we first examined what type of side activities they start and then their profiles (education, gender). This description will show what distinguishes these two groups. 


\section{Type of side activities}

A variety of side activities were found during the fieldwork. These are summarized in four main categories, namely tourism, services, the production and sale of products, and art, antiques and curios (Table 1). Activities related to tourism include mini-campsites, group accommodation, bed and breakfasts, and care-farms. Services include pedicure, manicure and massage, hairdressing, Pilates and yoga studios, and dog grooming. The products category includes products such as eggs, jam, cheese, honey, plants and flowers. The final category of art, antiques and curios includes galleries, ateliers, pottery and souvenir and craft shops.

Comparing side activities we observe that most farmers' activities were in the product category. This could be explained by the fact that this category includes farming and agriculturally-related products and could be seen as an extension of farmers' primary occupation. The rest of the categories are mainly initiated by nonfarmers, especially in the service and art sectors. Existing research notes differences and similarities between agricultural and non-agricultural firms in rural areas (Carter and Rosa 1998; Raley and Moxey 2000) but does not specifically capture figures on side activities. For example, Raley and Moxey (2000), examining rural micro-businesses in the UK, found a variety of activities initiated by non-farmers (tourism/recreation, manufacturing, retail, consultants and services), while the majority of the farmers $(60 \%)$ merely diversified their farms. Our results although indicative, show that farmers and non-farmers diversify their main income by practising a variety of side activities.

\begin{tabular}{|l|l|l|}
\hline \multicolumn{3}{|c|}{ Table 1: Categories of side activities, $n=84$} \\
\hline Side activity type & 70.3 & 29.7 \\
\hline Tourism & 93.8 & 6.2 \\
Services & 35.5 & 64.5 \\
Produce/sell products & 100.0 & 0.0 \\
Art, antique, curios & & \\
\hline
\end{tabular}

\section{Education level}

Education level can be a determining factor for participating in the labour market. A higher level of education also has a positive influence on starting a new business (Shane 2000; Venkataraman 1997). It is thus to be expected that people with higher education levels will be over-represented when it comes to starting side activities because they are better able to discover opportunities (Venkataraman 1997). According to Benjamin (1994), the higher the level of education, the higher the expectation that people will participate in off-farm labour.

The education system in the Netherlands can be divided into three main categories: lower, which is the basic and the compulsory education, secondary, which includes or included high schools, gymnasiums, lyceums, middle schools, vocational schools and preparatory schools, and higher education, including universities and professional colleges (Nuffic 2007). According to Broersma et al. (2010), 23\% of the Dutch population in employment in the five municipalities has lower education, $49 \%$ secondary and $27 \%$ higher. If we compare these figures with the results from this study, we find that there are major differences between the two side-activity owner groups.

In these five municipalities there is a tendency for non-farmers with side activities to have a higher level of education than farmers (Table 2). Forty-seven percent of non-farmers have a high level of education, whereas the largest group for farmers comprised those with secondary education (38\%). This is possibly explained by 
differences in the type of side activity. For example, managing an art gallery requires different skills and knowledge than selling farm products. If we then compare the results with the Dutch working population in these municipalities, we can conclude that the average level of education among side-activity owners is higher than the working population in these municipalities. This indicates that more highly educated people and especially non-farmers - are more inclined to start side activities.

\begin{tabular}{|c|c|c|c|}
\hline \multicolumn{4}{|c|}{ Table 2: The profile of farmers and non-farmers } \\
\hline & $\begin{array}{c}\text { Non } \\
\text { Farmers }\end{array}$ & Farmers & Total \\
\hline Count $(\mathrm{N})$ & 60 & 24 & 84 \\
\hline$\%$ & $71 \%$ & $29 \%$ & $100 \%$ \\
\hline \multicolumn{4}{|c|}{$\begin{array}{l}\text { Own database } \\
\text { Educational level }\end{array}$} \\
\hline Low & $12 \%$ & $29 \%$ & $23 \%$ \\
\hline Secondary & $40 \%$ & $38 \%$ & $49 \%$ \\
\hline Higher & $47 \%$ & $22 \%$ & $27 \%$ \\
\hline Other & $1 \%$ & $13 \%$ & $1 \%$ \\
\hline Total & $100 \%$ & $100 \%$ & $100 \%$ \\
\hline \multicolumn{4}{|c|}{ Gender } \\
\hline Men & $55 \%$ & $42 \%$ & $49 \%$ \\
\hline Women & $37 \%$ & $46 \%$ & $51 \%$ \\
\hline Together & $8 \%$ & $12 \%$ & - \\
\hline Total & $100 \%$ & $100 \%$ & $100 \%$ \\
\hline \multicolumn{4}{|c|}{ Age } \\
\hline $0-24$ & - & - & - \\
\hline $25-39$ & $17 \%$ & $17 \%$ & $27 \%$ \\
\hline $40-65$ & $73 \%$ & $79 \%$ & $53 \%$ \\
\hline $65+$ & $10 \%$ & $4 \%$ & $20 \%$ \\
\hline Total & $100 \%$ & $100 \%$ & $100 \%$ \\
\hline
\end{tabular}

* Data retrieved from Broersma et al. 2010 (working Dutch population of both men and women). Gender and age were retrieved from the Office of National Statistics (CBS, 2008).

\section{Gender}

Women's increased participation in off-farm work is well documented in Western Europe (Bock 2004; Haugen and Blekesaune 2005). Empirical evidence shows that women's off-farm work can be viewed as an important contribution to the farm household income (Eikeland and Lie 1999). Based on the findings in the literature, we expect women to be occupied not only with the household but also with activities outside domestic duties.

This study found that women from farm households are more likely to start side activities than women from non-farm households. Women from farming families score higher (46\%) than women from non-farming families (37\%). One way of explaining the results is that farmers' wives may have more opportunities to start activities than women in non-farming families because they may have more resources on the farm, better networks, free time or even fewer opportunities to have social contacts in other ways. The results also show that women from farming households score higher $(46 \%)$ than men $(42 \%)$, indicating that women are predominantly engaged in this type of 
activity and, as Bock (2004) argues, that it is often a spouse who takes the first step and builds up a new business.

As far as men are concerned, the results showed that non-farmers are more likely to start side activities (55\%) than farmers (42\%). Farmers are mostly occupied with farming activities rather than with side activities (Table 2).

So far, we have described the profiles of the two groups, farmers and nonfarmers. However, it is important to explore the future potential of side activities in rural areas and their potential effect on rural development. One way of doing this is by examining their motivations.

\section{Motivations}

Many studies have been devoted to identifying what motivates people to start a business (e.g. Cromie 1987; Wagner and Ziltener 2008). Neoclassical economic theory emphasizes the importance of economic rationality and the significance of profitmaximizing behaviour. However, in reality, people begin their own businesses for more diverse reasons. Quality of life, socio-psychological wellbeing and income generation have been reported as vital for new business creation (Hayter 1998). Non-economic considerations and the high value placed on independence and being one's own boss have also been reported from various studies (e.g. Feldman and Bolino 2000).

Similar research about motivations for starting a secondary activity on a farm has been done by many researchers (Gasson 1988; Van Huylenbroeck et al. 2004). Gasson (1988), for example, presents eight categories of perceived benefits as a result of part-time farming from a survey including 700 farmers in the UK and Wales (Income, Capital appreciation, Employment, Social contacts, Complementary relationships, Information, Hobby and Lifestyle). The results of her research show that income was the leading consideration, suggesting that farmers are motivated mainly by extrinsic motivations. Hobby, interests and lifestyle appear at the end of the list.

For this study, we divided the motivations into intrinsic and extrinsic. Intrinsic motivation is where a person is internally motivated to start a side activity because it satisfies that person's interests, brings pleasure, the opportunity to create social contacts or the need for personal development. Extrinsic motivation is where a person is motivated by factors such as the need for extra income, the need for employment or the investment of capital (Hessels et al. 2008; Waterman 2005).

When comparing the motivations of farmers and non-farmers we assume that non-farmers are motivated mainly by intrinsic motivations and farmers by extrinsic ones. This assumption is based on the fact that farmers are engaged in new activities in order to survive, to decrease their dependence on agricultural production and because they have resources such as time and networks (Gasson 1988; Herslund 2007; Van Huylenbroeck et al. 2004). We do not know much about non-farmer side activities from previous studies. The side activities may be started for various reasons. For this study we assumed that side activities are started on the basis of intrinsic motives. This assumption is because side activities by definition do not provide a primary source of income, meaning that those who do start them are probably intrinsically motivated.

For this study, the respondents were asked an open question to indicate what their motivations were to start their side activity. We categorized the motivations on the basis of the responses into 1) Hobby and own interests (intrinsic), 2) Income/economic reasons (extrinsic), 3) Social contacts (intrinsic), 4) Independence (intrinsic), 5) Availability of personal resources (extrinsic), 6) Unemployment (extrinsic), and 7) Other (including motivations that could not be classified into distinct categories: 
demand for the product, work from home, stay home with kids, medical reasons) (Figure 1).

The results indicate that farmers are indeed more extrinsically motivated than non-farmers. Income considerations score considerably higher for farmers $(32 \%)$ than for non-farmers $(21 \%)$.

The non-farmers group is mostly intrinsically motivated. Hobby and interests as motivation are more important to non-farmers $(52 \%)$ than to farmers $(38 \%)$, as is social contact. It is worth mentioning that the farmer group also stated that the pursuit of a hobby was their main motivation. However, compared to the non-farmer group, this is less important (Figure 1). The results contrast with Gasson's study (1988), where she argues that hobbies and lifestyle appeared to be the least important motives for part-time farming. The differences between our results and Gasson's may be related to the fact that her study was performed twenty years ago and that at that time agricultural decline was not that much of an issue. Accordingly, farmers did not often engage in side activities to decrease their dependence on agricultural activities. Furthermore, the availability of personal resources scores higher for farmers $(12 \%)$ than non-farmers $(1 \%)$. This is because farmers already have the available resources to start a new activity on the farm (e.g., land, space), whereas non-farmers might not.

To sum up, non-farmers start side activities driven mainly by intrinsic motivations, whereas farmers are more likely to be driven by extrinsic motivations. To be more specific, intrinsic motivations (e.g., hobby, social contacts, independence) score higher for non-farmers $(71 \%)$ than for farmers $(56 \%)$. Farmers are more interested in earning extra income. Non-farmers are mainly interested in supporting their hobbies and interests, whereas income is also a factor, but not their main consideration. Income considerations play a more significant role for farmers when setting up side activities.

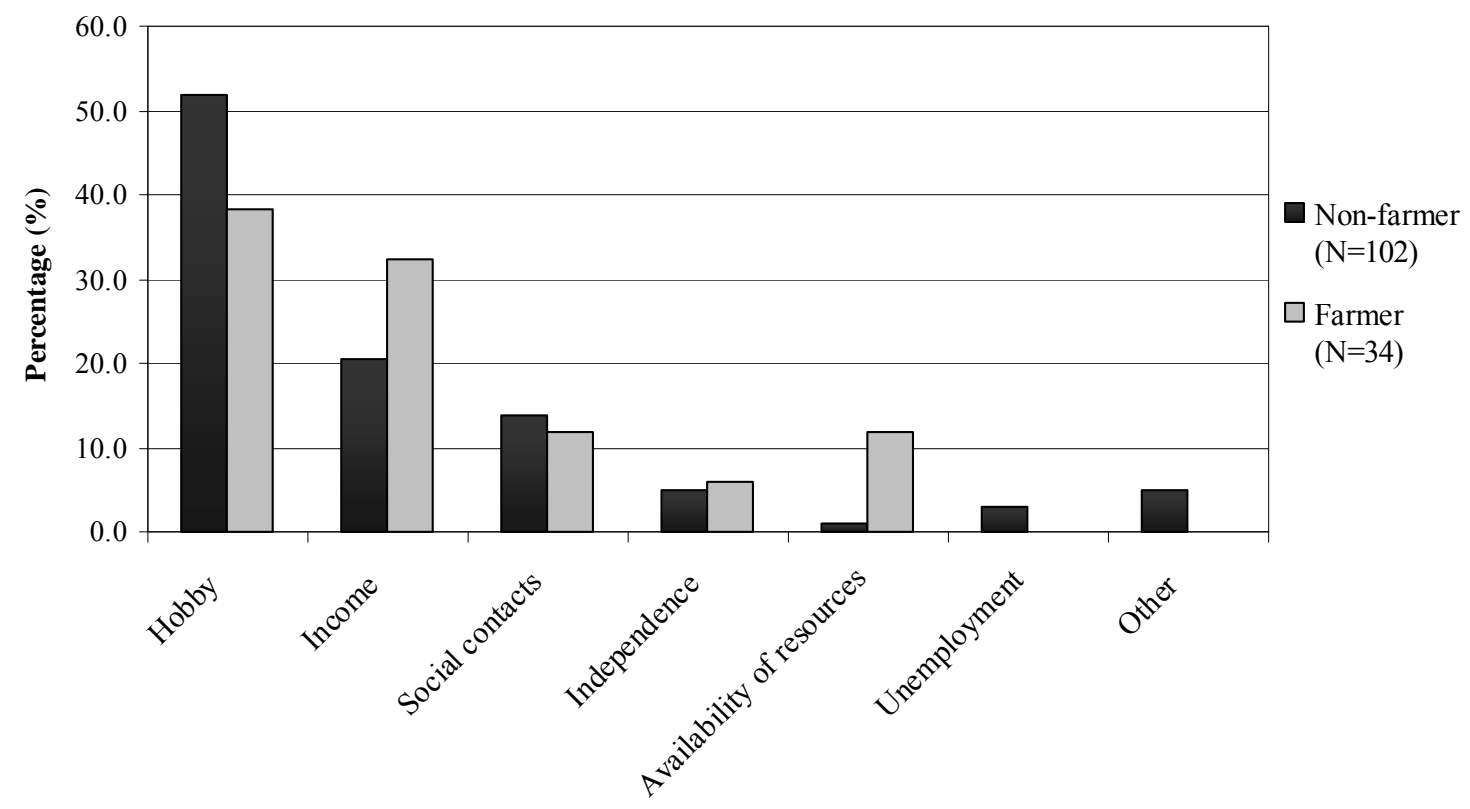

Figure 1: Motivations to start a side activity for farmers and non-farmers [The respondents could indicate more than one motive for starting their side activities]

\section{Conclusions}

As stated in the introduction, the focus of this paper is on side activities conducted by non-farmers and how they compare with farmers. Regarding the main driving force to start a side activity, non-farmers were mainly intrinsically motivated by 
their desire to start a hobby, enjoy the activity and to have social contacts. Economic considerations were also present but are not the main goal. On the contrary, farmers were mainly extrinsically motivated to start side activities. Economic considerations played a more important role for farmers. The fact that non-farmers are mainly motivated by their hobbies suggests that their side activities will probably remain small scale. This means that these activities will not disturb the landscape but may add to the attractiveness of the countryside for tourists and for local residents.

From a macro point of view, the initiation of side activities by farmers and nonfarmers in rural areas could have implications on rural development and more specifically, on local communities. Although many side activities are on a small scale and will probably not yield much direct economic benefit, they are important nonetheless because of their number and their diversity. The results of this study suggest that non-farmers may have a more important role in stimulating new activities in rural areas than has previously been considered. Non-farmers can contribute to the expansion of social networks and the viability of rural areas (Freshwater 2000).

From a policy point of view, rural side activities may have specific policy relevance in the near future by offering new opportunities for rural development. In this respect, policy intervention and support may play a positive role in encouraging and stimulating new economic activities in rural areas by offering funds or subsidies to nonfarmers.

In sum, despite the potential role of side activities by non-farmers in rural areas, there is usually an inadequate recognition of their importance in improving the character and the attractiveness of the countryside, in enhancing the quality of life in rural areas and in contributing to social life. By performing a more in-depth examination of nonfarmer side activities, we can contribute to their potential role in stimulating rural development and creating new opportunities. They may thus enhance the quality of life in rural areas and can be seen as a challenge through which diversification of activities in rural areas can be obtained.

\section{Acknowledgements}

The authors would like to thank Jelmer Folkertsma, Marleen Das, Matthijs Groeneveld, Gerlof Langhout, Gerjan Kamphuis, Robert Mackaaij, Erik ten Veen and Jeroen Visschers for their share in collecting the data. Many thanks to Lourens Broersma for the valuable statistical data. We would also like to thank the two anonymous referees for their comments on an earlier version of this paper. This research was made possible by a scholarship from the Onassis Foundation (Greece).

\section{References}

Benjamin, C. (1994), 'The growing importance of diversification activities for French farm households', Journal of Rural Studies 10:4, 331-342.

Bock, B. (2004), 'Fitting in and Multi-tasking: Dutch Farm Women's Strategies in Rural Entrepreneurship', Sociologia Ruralis 44:3, 245-260.

Broekhuizen, R., van Cooten, A. and Long, A. (1997), Renewing the countryside (Doetinchem: Misset).

Broersma, L., Edzes, A. and van Dijk, J. (2010), 'Higher education and economic performance: what are the mechanisms at work?', unpublished manuscript, University of Groningen.

Carter, S. (2001), 'Multiple business ownership in the farm sector - Differentiating monoactive, diversified and portfolio enterprises', International Journal of Entrepreneurial Behaviour \& Research 7:2, 43-59. 
Carter, S. and Rosa, P. (1998), 'Indigenous Rural Firms: Farm Enterprises in the UK', International Small Business Journal 16:4, 15-27.

CBS, (2008), Bevolking op 1 januari 2008, geslacht, leeftijd, burgerlijke staat en regio, Centraal Bureau voor de Statistiek (Statline databank), <http://statline.cbs.nl $>$.

Cromie, S. (1987), 'Motivations of Aspiring Male and Female Entrepreneurs', Journal of Occupational Behaviour 8:3, 251-261.

Eikeland, S. and Lie, I. (1999), 'Pluriactivity in rural Norway', Journal of Rural Studies $15: 4,405-415$.

Feldman, D.C. and Bolino, M.C. (2000), 'Career Patterns of the Self-Employed: Career Motivations and Career Outcomes', Journal of Small Business Management 38:3, 53-67.

Freshwater, D. (2000), 'The "New" Open Economy: What Has Changed For Rural Areas?' European Rural Policy At The Crossroads Conference, 29 June- 1 July 2000, University of Aberdeen, Scotland.

Gasson, R. (1988), The economics of part-time farming (Harlow: Longman Scientific \& Technical).

Gurria, A. (2007), 'Innovation in Rural Areas: an Exception or a Must?' (Speaker presentation), Innovative Rural Regions. The Role of Human Capital and Technology, OECD Rural Conference, 21-23 March 2007, Cáceres, Spain.

Haugen, M.S. and Blekesaune, A. (2005), 'Farm and Off-farm Work and Life Satisfaction among Norwegian Farm Women', Sociologia Ruralis 45:1-2, 71-85.

Hayter, R. (1998), The dynamics of industrial location the factory, the firm and the production system (Chichester: Wiley).

Herslund, L. (2007), 'Rural diversification in the Baltic countryside: a local perspective', GeoJournal 70:1, 47-59.

Hessels, J., van Gelderen, M. and Thurik, R. (2008), 'Drivers of entrepreneurial aspirations at the country level: the role of start-up motivations and social security', The International Entrepreneurship and Management Journal 4:4, 401-417.

Ilbery, B. (1998), The Geography of Rural Change (Harlow: Longman).

Nuffic, (2007), 'The Education System in The Netherlands', Netherlands Organization for International Cooperation in Higher Education, <http://www.nuffic.nl $>$

O'Connor, D., Renting, H., Gorman, M. and Kinsella, J. (2006), Driving rural development: policy and practice in seven EU countries (Assen: Koninklijke Van Gorcum).

Oksa, J. (1991), 'New activities in rural areas', Sociologia Ruralis 31:1, 9-16.

Raley, M. and Moxey, A. (2000), 'Rural Microbusinesses in the North East of England'. Final Survey Results: Newcastle upon Tyne: Centre for Rural Economy, Department of Agricultural Economics and Food Marketing, University of Newcastle.

Shane, S.A. (2000), 'Prior Knowledge and the Discovery of Entrepreneurial Opportunities', Organization Science 11:4, 448-469.

Van Depoele, L. (2000), 'The European Model of Agriculture (EMA): Multifunctional Agriculture and Multisectoral Rural Development', European Rural Policy at the Crossroads Conference, 29 June-1 July 2000, The Arkleton Centre for Rural Development Research, Scotland.

Van der Ploeg, J. D. (2003), The virtual farmer past, present, and future of the Dutch peasantry (Assen: Koninklijke Van Gorcum). 
Van Huylenbroeck, G., Durand, G. and Thomson, K. (2004), Multifunctional Agriculture A New Paradigm for European Agriculture and Rural Development (Hamphire: Ashgate).

Venkataraman, S. (1997), 'The distinctive domain of entrepreneurship research: An editor's perspective', in J. Katz and R.H. Brockhaus (eds), Advances in entrepreneurship, firm emergence, and growth (Greenwich, CT: JAI Press).

Wagner, K. and Ziltener, A. (2008), 'The Nascent Entrepreneur at the Crossroads: Entrepreneurial Motives as Determinants for the Different Types of Entrepreneurs', Discussion Papers on Entrepreneurship and Innovation, Swiss Institute for Entrepreneurship, Chur.

Waterman, A. (2005), 'When Effort Is Enjoyed: Two Studies of Intrinsic Motivation for Personally Salient Activities', Motivation and Emotion 29:3, 165-188. 